\title{
Pulse Oximeter with Internet Data Visualization
}

Gabriel Contreras Mota / gabriel.contreras.217@gmail.com

Rafael Lemuz López / rafael.lemuz@correo.buap.mx

Cesar Bautista Ramos / cesar.bautista@correo.buap.mx

Facultad de Ciencias de la Computación, Benemérita Universidad Autónoma de Puebla, México

ABSTRACT In this work, we describe the design and construction of a pulse oximeter for remote patient monitoring. The proposed device uses the ESP8266 microcontroller as the core component to establish the wireless connection and send information to a node.js server. Then, a web service shows the saturation of oxygen and the heart rate through a WebSocket connection. This paper describes the hardware and software designs, justifying the decision to select each component of the proposed device. Finally, some experimental results are shown to illustrate the performance of the developed prototype.

KEYWORDS Pulse; oximeter; WebSoket; node.js; microcontroller; ESP8266.

Oxímetro de pulso con visualización de datos en Internet

RESUMEN En este trabajo se describe el diseño y la construcción de un oxímetro de pulso para el monitoreo de pacientes a distancia. El dispositivo propuesto utiliza el microcontrolador ESP8266 como componente principal para establecer la conexión inalámbrica y enviar la información a un servidor node.js. Además, un sistema web puede mostrar la saturación de oxígeno y la frecuencia del latido cardiaco a través de una conexión con WebSockets. En el artículo se describen los diseños del hardware y software del dispositivo, y se justifica la selección de cada uno de sus componentes. Finalmente, se muestran algunos resultados experimentales que ilustran el funcionamiento del prototipo desarrollado.

PALABRAS CLAVE Pulso; oxímetro; WebSokets, node.js; microcontrolador; ESP8266.
Oxímetro de pulso com visualização de dados na Internet

RESUMO Neste trabalho, descrevemos o desenho e a construção de um oxímetro de pulso para monitorar pacientes à distância. $\mathrm{O}$ dispositivo proposto usa o microcontrolador ESP8266 como o componente principal para estabelecer a conexão sem fio e enviar a informação para um servidor node.js. Além disso, um sistema web pode mostrar a saturação de oxigênio e a frequência cardíaca através de uma conexão com WebSockets. O artigo descreve os desenhos do hardware e do software do dispositivo e justifica a seleção de cada um dos seus componentes. Finalmente, são mostrados alguns resultados experimentais que ilustram o funcionamento do protótipo desenvolvido.

PALAVRAS-CHAVE Pulso; oxímetro; WebSokets, node.js; microcontrolador; ESP8266. 


\section{Introduction}

The pulse oximeter is a medical device used for the measurement of blood oxygen saturation SpO2 and heart rate. The measurement of oxygen in the blood has more than 150 years of history, with the advancement of technology, this device has had the opportunity to evolve, improve its accuracy and decrease its size, which has allowed access to a pulse oximeter to the population in general (López-Herranz, 2003).

The main foundation used in an oximeter is to use the physical properties of the reflection and absorption of light in a specific protein of the blood (hemoglobin), which when exposed to a certain wavelength, the way in which it absorbs and reflects the wavelengths of the light is different, depending on whether it transports oxygen [O2] or carbon dioxide [CO2]. From this variation, it is possible to calculate the percentage of oxygen in the blood.

The development of a pulse oximeter was proposed from the ESP8266 microcontroller, using the minimum electronic elements, to reduce the electrical consumption, reduce the size of the device and avoid the incursion of noise from analogous elements; the use of analogical components is replaced by digital ones, as is the case of filters. The device connects to a server wirelessly [WiFi] over the Internet and sends the signal captured by the sensor; subsequently, the data is filtered, processed and stored by a web application. The user can see these measurements stored or observe the measurement data in real time

Pulse oximeters are essential to move towards health monitoring devices remotely, either interacting with smartphones or integrated into the Internet.

Mejía Salas and Mejía Suarez (2012) present the design of a small and inexpensive pulse oximeter, suitable for portable applications, with real-time data transmission through a ZigBee wireless link or a USB cable connection to a host.

Gómez García and Velasco Medina (2014) describe the design of a pulse oximeter that incorporates configurable analog and digital blocks, which allow the adaptation of the signals supplied by the sensors and the digital signal processing to be carried out on the same chip. In addition, they present an Android app for the visualization and registration of biomedical signals in a local database, compatible with mobile devices with WiFi connectivity.

This paper describes the design of an oximeter that allows the transmission and visualization of data in real time in a web app.

\section{Introducción}

El oxímetro de pulso es un dispositivo médico utilizado en la medición de la saturación de oxígeno en la sangre $\mathrm{SpO} 2$ y el ritmo cardíaco. La medición del oxígeno en la sangre tiene más de 150 años de historia, con el avance de la tecnología, este dispositivo ha tenido la oportunidad de evolucionar, mejorar su precisión y disminuir su tamaño, lo que ha permitido el acceso a un oxímetro de pulso a la población en general (López-Herranz, 2003).

El fundamento principal empleado en un oxímetro es utilizar las propiedades físicas de la reflexión y absorción de la luz en una proteína específica de la sangre (la hemoglobina), la que al exponerse a cierta longitud de onda, la manera en la que absorbe y refleja las longitudes de onda de la luz es diferente, dependiendo si trasporta oxigeno [O2] o dióxido de carbono [CO2]. A partir de esta variación se puede calcular el porcentaje de oxígeno en la sangre.

Se planteó el desarrollo de un oxímetro de pulso a partir del microcontrolador ESP8266, utilizando los elementos electrónicos mínimos, para disminuir el consumo eléctrico, reducir el tamaño del dispositivo y evitar la incursión de ruido de elementos análogos; se remplaza el uso de componentes analógicos por digitales, como es el caso de los filtros. El dispositivo se conecta a un servidor de manera inalámbrica [WiFi] por Internet y envía la señal capturada por el sensor; posteriormente, los datos son filtrados, procesados y almacenados por una aplicación web. El usuario puede ver estas mediciones almacenadas u observar los datos de la medición en tiempo real.

Los oxímetros de pulso son fundamentales para avanzar hacia dispositivos de monitorización de la salud a distancia, ya sea interactuando con teléfonos inteligentes o integrados a la Internet.

Mejía Salas y Mejía Suarez (2012) presentan el diseño de un oxímetro de pulso pequeño y de bajo costo, apropiado para aplicaciones portátiles, con transmisión de datos en tiempo real a través de un enlace inalámbrico ZigBee o una conexión USB por cable a un host.

Gómez García y Velasco Medina (2014) describen el diseño de un oxímetro de pulso que incorpora bloques análogos y digitales configurables, que permiten que la adecuación de las señales suministradas por los sensores y el procesamiento digital de señales se lleve a cabo en el mismo chip. Además, presentan una aplicación en Android para la visualización y el registro de las señales biomédicas en una base de datos local, compatible con dispositivos móviles con conectividad WiFi.

En este trabajo se describe el diseño de un oxímetro que permite la transmisión y visualización de datos en tiempo real en una aplicación web.

\section{Marco teórico}

La oximetría de pulso es un método de medición utilizado en distintos ámbitos clínicos como: las intervenciones quirúrgicas; el control y tratamiento de EPOG [Enfermedad Pulmonar Obstructiva Crónica]; el seguimiento del asma; el diagnóstico y desarrollo de enfermedades respiratorias, como la influenza; y en las unidades de cuidados intensivos. El dispositivo utiliza las propiedades físicas de la absorción de la luz de la hemog- 
lobina para determinar el porcentaje de saturación de oxígeno en la sangre (Li \& Warren, 2012).

\section{Hemoglobina}

La hemoglobina es una proteína presente en los glóbulos rojos de la sangre, se genera en la médula ósea y es la encargada de transportar el oxígeno desde los pulmones hacia los tejidos del cuerpo, en su retorno a los pulmones trasporta CO2, para su eliminación (Peñuela, 2005). Cuando la hemoglobina lleva oxigeno, se denomina oxihemoglobina y es de un color rojo intenso; cuanto transporta dióxido de carbono, se denomina desoxihemoglobina y es de un color rojo azulado.

\section{Frecuencia cardiana}

La circulación de la sangre se debe al trabajo del corazón, el cual bombea sangre a cada parte del cuerpo, así esta puede llevar a cabo su función de trasporte, protección y regulación; la hemoglobina es la encargada del trasporte de gases (Koolman \& Röhm, 2005). El movimiento generado por el corazón puede medirse contando las contracciones que el ventrículo izquierdo ejerce en determinado tiempo, a esto se le llama frecuencia cardíaca (Font, Pedret, Ramos, \& Ortís, 2008).

\section{Principios básicos}

Para realizar la medición de los niveles de oxígeno en la sangre, la oximetría de pulso usa dos técnicas: la espectrofotometría, fundamentada en la Ley de Lambert-Beer que utiliza la absorción de cierta onda de luz para determinar la cantidad en cierto elemento, dependido de la estructura de cada molécula (Marczenko, Balcerzak, \& Kloczko, 2000); y la pletismografía, que mide los cambios del volumen de la sangre en el cuerpo. En este último caso, al usar métodos ópticos se denomina fotopletismografía (Abu-Rahma \& Bandyk, 2012).

Se necesita irradiar a las dos sustancias a medir con dos longitudes de onda distintas, en este caso la hemoglobina, que reacciona de manera distinta al tener presente oxigeno o dióxido de carbono. Como se puede ver en la Figura 1, la oxihemoglobina absorbe más luz con frecuencias de 910 a 940 nanómetros, y la desoxihemoglobina lo hace en el rango de rojo de 640 a 660 nanómetros.

El oxímetro de pulso puede emplear dos tipos de detección: por reflectancia, que se basa en la luz que refleja la sangre; y por transmitancia, que utiliza la absorción de luz. En este proyecto se emplea el método por transmitancia, el dispositivo cuenta con dos emisores situados al frente del sensor; la medi-

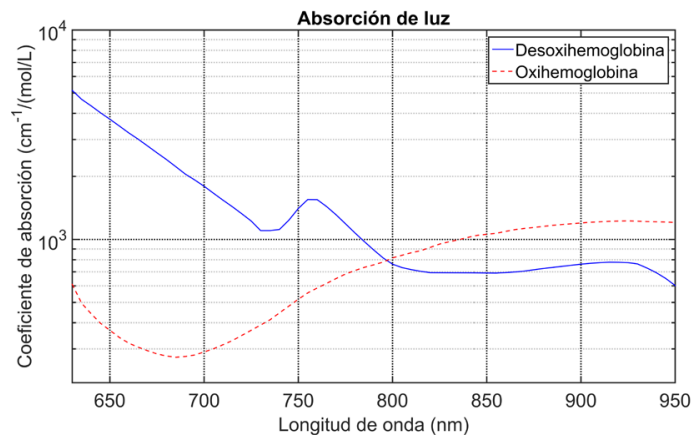

Figure 1. Absorption of light waves / Absorción de las ondas luz

\section{Theoretical Framework}

Pulse oximetry is a measurement method used in different clinical areas such as surgical interventions; the control and treatment of COPD [Chronic Obstructive Pulmonary Disease]; the monitoring of asthma; the diagnosis and development of respiratory diseases, such as influenza; and in the intensive care units. The device uses the physical properties of light absorption of hemoglobin to determine the percentage of oxygen saturation in the blood (Li, 2012).

\section{Hemoglobin}

Hemoglobin is a protein present in the red blood cells, it is generated in the bone marrow and is responsible for transporting oxygen from the lungs to the tissues of the body, on its return to the lungs transports $\mathrm{CO} 2$, for its elimination (Peñuela, 2005). When hemoglobin carries oxygen, it is called oxyhemoglobin and it is an intense red color; when it transports carbon dioxide, it is called DE-oxyhemoglobin and it has a bluish red color.

\section{Heart Rate}

The circulation of blood is due to the work of the heart, which pumps blood to every part of the body, so it can carry out its function of transport, protection, and regulation; hemoglobin is responsible for the transport of gases (Koolman \& Röhm, 2005). The movement generated by the heart can be measured by counting the contractions that the left ventricle exerts in a certain time, this is called heart rate (Font, Pedret, Ramos, \& Ortís, 2008).

\section{Basic Principles}

To perform the measurement of oxygen levels in the blood, pulse oximetry uses two techniques: spectrophotometry, based on Lambert-Beer Law that uses the absorption of a certain light wave to determine the amount in a certain element, depending on of the structure of each molecule (Marczenko, Balcerzak, \& Kloczko, 2000); and plethysmography, which measures changes in the volume of blood in the body. In the latter case, using optical methods is called photo-plethysmography (Abu-Rahma \& Bandyk, 2012).

It is necessary to irradiate the two substances to be measured with two different wavelengths, in this case, the hemoglobin, which reacts differently when having oxygen or carbon dioxide present. As can be seen in FIgURE 1, oxyhemoglobin absorbs more light with frequencies of 910 to 940 nanometers, and DE-oxyhemoglobin does so in the red range of 640 to 660 nanometers. 
The pulse oximeter can employ two types of detection: by reflectance, which is based on the light that reflects the blood; and by transmittance, which uses the absorption of light. In this project, the transmittance method is used, the device has two transmitters located in front of the sensor; the measurement is made on the finger (Webster, 1997). Figure 2 shows the structure of the device and the position of the components that comprise it.

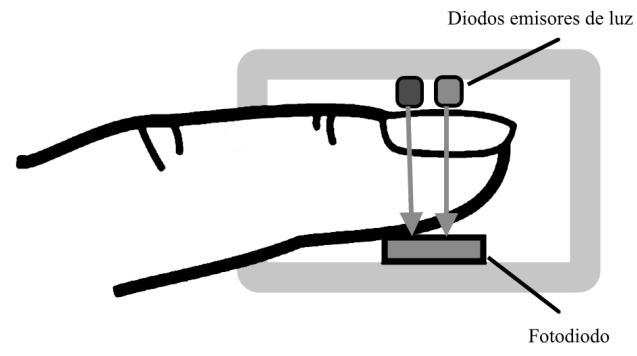

Figure 2. Diagram of the device clip / Esquema del clip del dispositivo

\section{Lambert-Beer Law}

The Lambert-Beer law is the principle that uses the pulse oximeter to perform the measurement of $\mathrm{SpO} 2$ in the blood, this law expresses how the absorbance in a certain wave of light can be measured on a substance, which will depend on the concentration of the absorbent compound, the distance and the type of light wave.

\section{Photoplethyographic Signal}

The measurement is obtained by radiating one side of the finger with the corresponding light frequency in different time intervals; at the other end is the sensor that captures all changes in the signal.

The wave of light passes through the arterial blood, known as the dynamic or alternating part [AC] and the continuous or static part [DG] formed by tissues, bone, nail and skin, until reaching the sensor (Bencomo, Villazana, \& Salas, 2016), as can be seen in Figure 3. We are interested in analyzing the AC signal, discarding the static component, this signal is only perceived when there is a pulse present, otherwise, it could not be detected, as mentioned.

Obtained the two signals we cannot directly use the Lambert-Beer law to use two wavelengths. Therefore, we use equation 1 , which determines the ratio that describes the difference between the two wavelengths:

$$
R=\frac{\frac{A C_{\text {red }}}{D C_{\text {red }}}}{\frac{A C_{\text {infrared }}}{D C_{\text {infrared }}}} \quad \text { Equation } 1
$$

ción se efectúa en el dedo de la mano (Webster, 1997). En la Figura 2 se observa la estructura del dispositivo y la posición de los componentes que lo conforman.

\section{Ley de Lambert-Beer}

La ley de Lambert-Beer es el principio que utiliza el oxímetro de pulso para realizar la medición del SpO2 en la sangre, esta ley expresa cómo se puede medir la absorbancia en determinada onda de luz sobre una sustancia, la que dependerá de la concentración del compuesto absorbente, la distancia y el tipo de onda de luz.

\section{Señal fotopletimográfica}

La obtención de la medición se realiza radiando un lado del dedo con la frecuencia de luz correspondiente en diferentes intervalos de tiempo; por el otro extremo se encuentra el sensor que capta todos los cambios en la señal.

La onda de luz atraviesa la sangre arterial, conocida como la parte dinámica o alterna [AC] y la parte continua o estática [DC] conformada por tejidos, hueso, uña y piel, hasta llegar al sensor (Bencomo, Villazana, \& Salas, 2016), como se pude observar en la Figura 3. Nos interesa analizar la señal AC, descartando la componente estática, esta señal es percibida solo cuando hay pulso presente, de otra forma no podría detectarse, por lo mencionado.

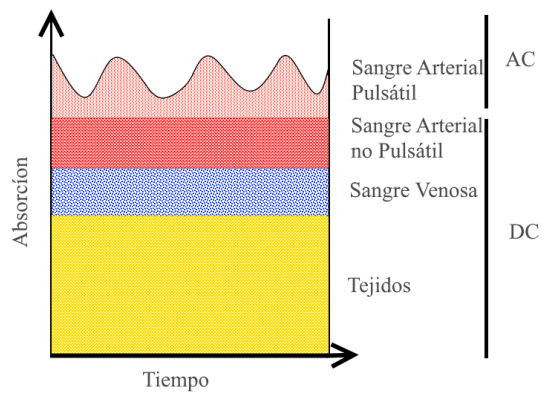

Figure 3. Components comprising the finger / Componentes que conforman al dedo

Obtenidas las dos señales no podemos usar directamente la ley de Lambert-Beer por utilizar dos longitudes de onda, para ello utilizamos la ecuación 1, la cual determina la razón que describe la diferencia entre las dos longitudes de ondas:

$$
R=\frac{\frac{A C_{\text {red }}}{D C_{\text {red }}}}{\frac{A C_{\text {infrared }}}{D C_{\text {infrared }}}} \quad \text { Ecuación } 1
$$

\section{Diseño y construcción \\ Emisores y sensor}

La oximetría hace uso de la radiación de dos frecuencias de luz para detectar la saturación de oxígeno, se emplea dos diodos emisores de luz, con las frecuencias de 640nm-660nm (rojo) y de $910 \mathrm{~nm}-940 \mathrm{~nm}$ (infrarrojo). Estos leds se encienden alternadamente en un intervalo de tiempo definido.

El sensor encargado de captar la variación de las frecuencias de luz que atraviesa el dedo del usuario es el OPT101 de Texas 
Instruments [TI]; el integrado es un foto-diodo monolítico que cuenta con un amplificador de transimpedancia que genera una salida reducida en ruido o picos, con un rango de frecuencia de onda efectivo que va de los 400nm a los $1100 \mathrm{~nm}$ (TI, 2015).

\section{Convertidor $A D C$}

La obtención de la señal de salida del sensor para su envío y posterior procesamiento debe ser convertida a valores que el dispositivo pueda manipular, al ser transformada de su forma analógica a digital se necesita que el convertidor sea de alta resolución, para diferenciar los cambios de la onda pulsátil, ya que de la señal obtenida solo el $2 \%$ corresponde a los valores de la sangre arterial. El dispositivo empleado es el ADS1115, desarrollado por TI. Él, cuenta con una resolución de 16 bits, integra una PGA para la amplificación de la señal, y lleva la comunicación con el microcontrolador mediante el protocolo I2C (TI, 2016).

\section{ESP8266}

El chip ESP8266 fabricado por Espressif originalmente inicio como un módulo Wi-Fi de bajo costo, capaz de realizar las conexiones TCP/IP, el cual era controlado por otro microcontrolador a través de comandos AT. Tiempo después, la empresa libero el SDK que le permitía al chip la autonomía para no depender de otro microcontrolador, el dispositivo podía ser programado y funcionar de manera autónoma (Espressif, 2017). Con el tiempo, se empezaron a utilizar firmwares de terceros y el compilador nativo GCG permitió que el dispositivo pudiera correr MicroPython, LUA y Arduino.

Control de los LED y obtención de datos

Se inicia el control de los LED y la captura del fotodiodo. En la Figura 4 se muestra la señal empleada para el control de los LED emisores, cada periodo toma $1 \mathrm{~ms}$ en el cual cada estado de alto y bajo dura 250 ns; para tener una medición completa y enviar los datos se implementa en un ciclo de 256 mediciones.

\section{Envío de los datos}

Cuando el chip completa la lectura, se procede al envío de los datos al servidor. La comunicación se lleva a cabo por el protocolo de WebSockets. Esta API proporciona una comunicación bidireccional entre cliente y servidor sobre una conexión de TCP (Chopra, 2015), el chip realiza conexiones HTTP y TCP de manera nativa, por lo que se pueden implementar los protocolos de WebSocket. Para realizar una conexión, inicialmente la petición se realiza en HTTP, en ella, el cliente le pide al

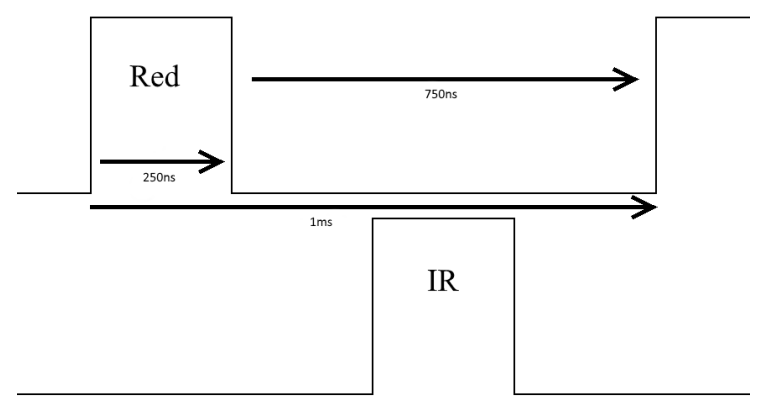

Figure 4. Control signal of the two emitting diodes / Señal de control de los dos diodos emisores

\section{Design and Construction}

\section{Emitters and Sensor}

The oximetry makes use of the radiation of two frequencies of light to detect oxygen saturation, using two light-emitting diodes, with the frequencies of $640 \mathrm{~nm}-$ 660nm (red) and 910nm-940nm (infrared). These LEDs turn on alternately in a defined time interval.

The sensor responsible for capturing the variation of light frequencies that pass through the user's finger is the Texas Instruments OPT101 [T]; the integrated one is a monolithic photo-diode that has a transimpedance amplifier that generates a reduced output in noise or peaks, with an effective wave frequency range ranging from $400 \mathrm{~nm}$ to $1100 \mathrm{~nm}$ (TI, 2015).

\section{$A D C$ Converter}

The obtaining of the signal of exit of the sensor for its sending and later processing must be converted to values that the device can manipulate, to the being transformed of its analogical form to digital it is needed that the converter is of high resolution, to differentiate the changes of the pulsatile wave, since only $2 \%$ corresponds to the values of the arterial blood of the signal obtained. The device used is the ADS1115, developed by TI. It has a 16 bit resolution, integrates a PGA for signal amplification, and carries communication with the microcontroller through the I2C protocol (TI, 2016).

\section{ESP8266}

The ESP8266 chip manufactured by Espressif originally started as a low-cost Wi-Fi module, capable of making TCP / IP connections, which was controlled by another microcontroller through AT commands. Later, the company released the SDK that allowed the chip autonomy to not depend on another microcontroller, the device could be programmed and operate autonomously (Espressif, 2017). Over time, they started using third-party firmware and the native GCC compiler allowed the device to run MicroPython, LUA, and Arduino.

\section{LED Control and Data Acquisition}

The control of the LEDs and the capture of the photodiode is started. Figure 4 shows the signal used to control the emitting LEDs, each period takes $1 \mathrm{~ms}$ in which each state of high and low lasts $250 \mathrm{~ns}$; to have a complete measurement and send the data is implemented in a cycle of 256 measurements. 


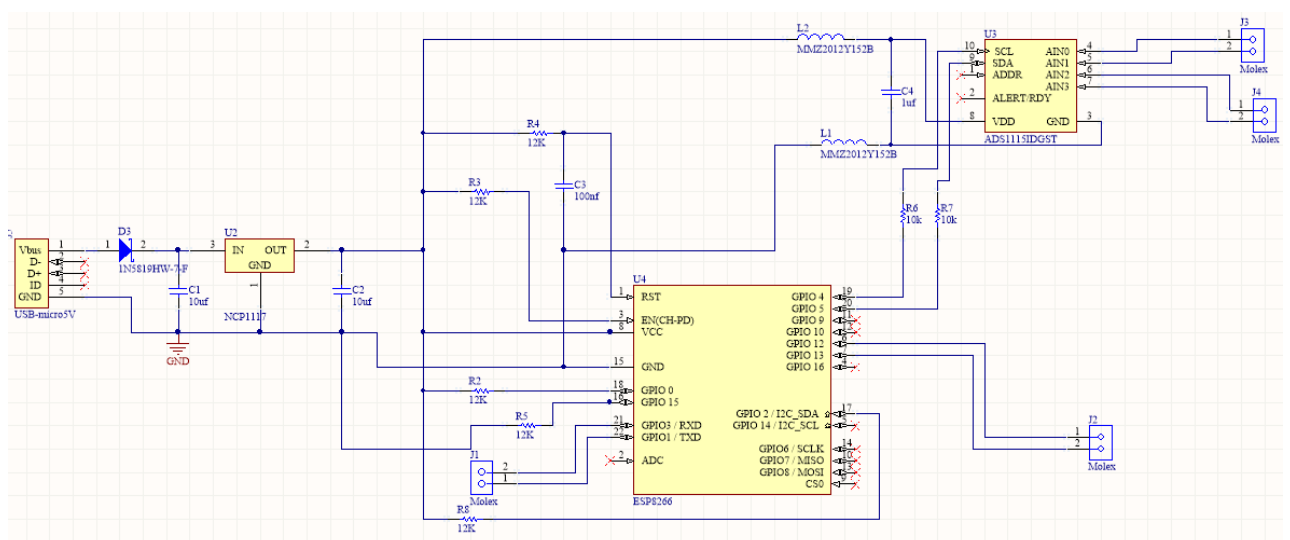

Figure 5. Diagram of the pulse oximeter: connection of the ESP8266 chip with the ADC 1115 / Esquema del oxímetro de pulso: conexión del chip ESP8266 con el ADC 1115

\section{Data Transmission}

When the chip completes the reading, it proceeds to send the data to the server. The communication is carried out by the Web-Sockets protocol. This API provides bidirectional communication between client and server over a TCP connection (Chopra, 2015), the chip makes HTTP and TCP connections natively so that Web-Socket protocols can be implemented. To make a connection, initially the request is made in HTTP, in it, the client asks the server to update the connection. Its advantage is a continuous link to the server, which allows the transmission of data in real time, with little latency.

\section{PCB}

The physical development of the device was designed based on the technical specifications of the component manufacturers; the realization of the schematics and the printed circuits was carried out in the free tool Circuit-Maker of the company Altium Limited.

The chip originally has an ADC at 10bit of 1 volt, which is insufficient for use in the oximeter; the ADC 1115 is integrated in a single plate, together with the ESP8266, in addition to a current regulation system to work at $5 \mathrm{v}$. It was reduced to the minimum of components using only those necessary for the operation of the oximeter. Figure 5 shows the scheme of the proposed system.

In Figure 6 you can see the PCB of the final device, 5 $\mathrm{cm}$ long and $3 \mathrm{~cm}$ wide. The device is powered by a micro USB connection, the choice of this input is due to the number of portable energy storage devices on the market.

\section{App Development}

For the implementation of the server and the web app of the oximeter, the platform of Node.js was used, it was decided to use this environment for ease of scala- servidor la actualización de la conexión. Tiene como ventaja un enlace continuo al servidor, lo que permite la transmisión de datos en tiempo real, con poca latencia.

\section{PCB}

El desarrollo fisico del dispositivo se diseñó a partir de las especificaciones técnicas de los fabricantes de los componentes; la realización de los esquemáticos y de los circuitos impresos se llevó a cabo en la herramienta gratuita CircuitMaker de la empresa Altium Limited.

El chip originalmente cuenta con un ADC a 10bit de 1 volt, que es insuficiente para el uso en el oxímetro; se integra en una sola placa el ADC 1115, junto con el ESP8266, además de un sistema de regulación de corriente para trabajar a $5 \mathrm{v}$. Se redujo al mínimo de componentes empleando solo los necesarios para el funcionamiento del oxímetro. En la Figura 5 se muestra el esquema del sistema propuesto.

En la Figura 6 se puede ver el PCB del dispositivo final, de 5 $\mathrm{cm}$ de largo y $3 \mathrm{~cm}$ de ancho. La alimentación del dispositivo se realiza mediante una conexión de micro USB, la elección de esta entrada se debe a la cantidad de dispositivos de almacenamiento de energía portátil existente en el mercado.

\section{Desarrollo de la aplicación}

Para la implementación del servidor y la aplicación web del oxímetro se utilizó la plataforma de Node.js, se decidió el uso de este entorno por la facilidad que escalabilidad y el manejo de eventos. Para la comunicación por medio de WebSockets, el servidor se encarga de recibir la señal capturada por el microcontrolador; una vez recibida, la señal se filtra y se envía al front-end para su visualización.
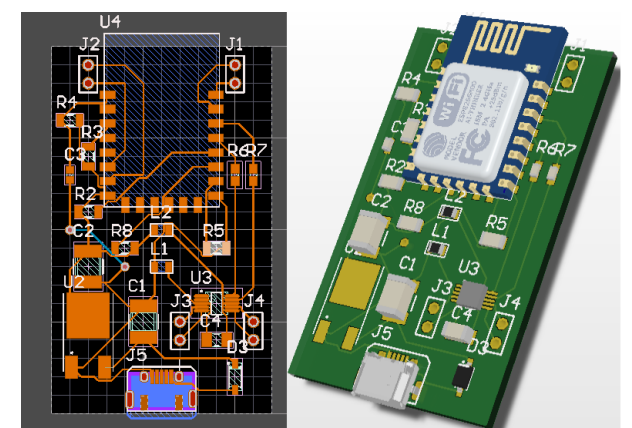

Figure 6. PCB of the proposed chip for the pulse oximeter / PCB del chip propuesto para el oxímetro de pulso 


\section{Filtrado}

Un filtro digital es un sistema programable encargado de procesar una señal previamente convertida a digital, una ventaja de este tipo de filtros es que puede ser implementado en dispositivos que cuenten con las características de procesamiento necesarias, dejando de lado el uso de dispositivos analógicos.

Una vez obtenida la señal digital, es necesario un proceso de filtrado para eliminar frecuencias fuera del rango que emplea el oxímetro, este límite se establece a partir de las pulsaciones del corazón.

El promedio de pulsaciones del corazón por minuto [ppm], para un individuo adulto en reposo es de entre 50 y 100. Las personas que realizan ejercicio frecuentemente son pueden llegar a 30 ppm en reposo, como máximo, el corazón puede soportar hasta 220ppm, aunque este valor varía dependiendo de la edad.

Para mantener una relación con respecto a las frecuencias máxima y mínima, se limitó a medir de 30 ppm a 300 ppm, lo que correspondería a $0.5 \mathrm{~Hz}$ y $5 \mathrm{~Hz}$. Para ello, se diseñó un filtro pasa banda FIR de tamaño 256. En la Figura 7 se puede observar la respuesta del filtro.
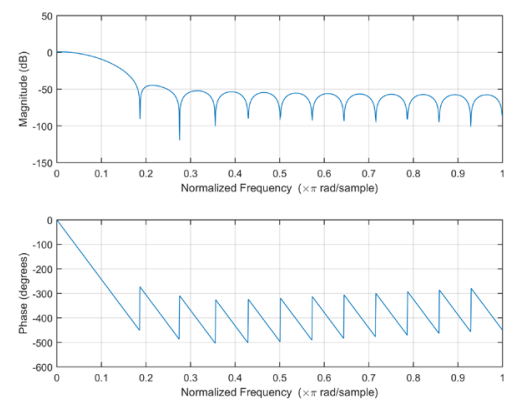

Figure 7. Passband filter response / Respuesta del filtro pasabanda

\section{Procesado}

Cuando el servidor recibe la señal esta filtra y envía las dos señales capturadas, la aplicación procesa la señal obtenida aplicando la Ecuación 1, y obtiene la razón entre las longitudes de onda; luego se establece el porcentaje a través de la curva generada, mediante un proceso de calibración (en este caso, la calibración se desarrolló de manera empírica, a través de mediciones y comparaciones).

En cuanto al pulso cardiaco, solo restaría aplicar la auto correlación de la señal. El valor de R se encuentra ligado al porcentaje de $\mathrm{SpO} 2$, una vez calibrado el equipo. Estos datos de comparación son guardados en el microcontrolador para su uso.

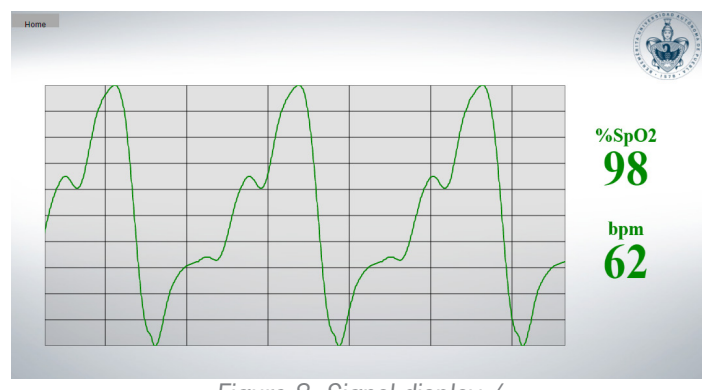

Figure 8. Signal display /

Visualización de la señal bility and event handling. For communication through Web-Sockets, the server is responsible for receiving the signal captured by the microcontroller; once received, the signal is filtered and sent to the front-end for viewing.

\section{Filtering}

A digital filter is a programmable system in charge of processing a signal previously converted to digital, an advantage of this type of filters is that it can be implemented in devices that have the necessary processing characteristics, leaving aside the use of analog devices.

Once the digital signal is obtained, a filtering process is necessary to eliminate frequencies outside the range used by the oximeter, this limit is established from the pulsations of the heart. The average heart rate per minute [ppm] for an adult at rest is between 50 and 100 . People who exercise frequently can reach 30 ppm at rest, at most, the heart can support up to 220ppm, although this value varies depending on the age.

To maintain a relationship with respect to the maximum and minimum frequencies, he limited himself to measuring from 30 ppm to 300 ppm, which would correspond to $0.5 \mathrm{~Hz}$ and $5 \mathrm{~Hz}$. For this purpose, an FIR bandpass filter of size 256 was designed. Figure 7 shows the response of the filter.

\section{Processing}

When the server receives the signal it filters and sends the two signals captured, the application processes the signal obtained by applying Equation 1, and obtains the ratio between the wavelengths; then the percentage is established through the generated curve, through a calibration process (in this case, the calibration was developed empirically, through measurements and comparisons).

As for the cardiac pulse, it would only be necessary to apply the self-correlation of the signal. The value of $\mathrm{R}$ is linked to the percentage of $\mathrm{SpO}$, once the equipment has been calibrated. This comparison data is stored in the microcontroller for its use.

\section{Visualization}

FIGURE 8 shows the data generated by the proposed oximeter. The system uses libraries in JavaScript that were modified for the visualization of the photolithographic signal. Two canvases are used for oxygen levels and cardiac pulse.

\section{Results}

The construction of the device was carried out using the elements mentioned in the previous sections, the first 
phase of the measurement of the pulse oximeter is carried out by the sensor and the emitter; these were built from the scheme made.

Having the armed cards of the sensor and emitter, measurements can be made. These should be one in front of the other, for it, the two cards are assembled in a finger clip built with sheets of foamed PVC, a light, rigid and durable material. Figure 9 shows the finished device. This clip is $6 \mathrm{~cm}$ long, $2.5 \mathrm{~cm}$ wide and $3 \mathrm{~cm}$ high.

The main core of the pulse oximeter formed by the ESP8266 device was placed on a wristband, just like the battery. In Figure 10 the final device is seen in operation.

The user can observe their oxygen levels in the blood and heart rate by entering the application site.

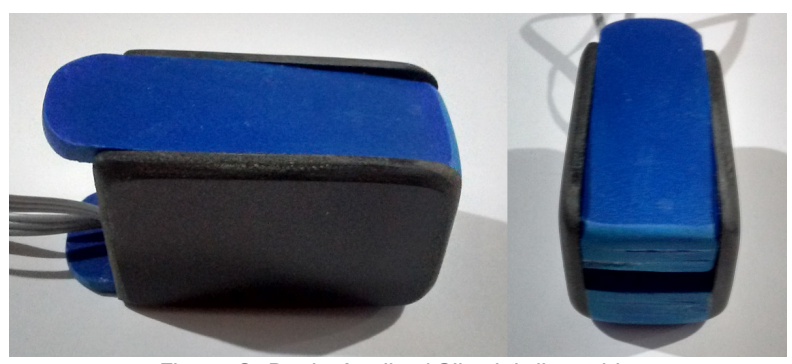

Figure 9. Device's clip / Clip del dispositivo

\section{Vl. Conclusion}

In this document was presented the prototype of a pulse oximeter based on the ESP8266 microcontroller with WiFi connection, which allows remote monitoring of oxygen saturation and cardiac pulse, it was possible to maintain a continuous monitoring, besides keeping a record of the same for further analysis. In the future, the aim is to improve the graphic environment, as well as the control of users, furthermore the implementation of this system to other vital signs. ST

\section{Visualización}

La Figura 8 muestra los datos generados por el oxímetro propuesto. El sistema emplea librerías en JavaScript que fueron modificadas para la visualización de la señal fotopletimográfica. Para los niveles de oxígeno y pulso cardiaco se utilizan dos lienzos.

\section{Resultados}

La construcción del dispositivo se llevó a cabo utilizando los elementos mencionados en las secciones anteriores, la primera fase de la medición del oxímetro de pulso se lleva a cabo por el sensor y el emisor; estos se construyeron a partir del esquema realizado.

Teniendo las tarjetas armadas del sensor y emisor, se pueden realizar las mediciones. Estas deben estar una en frente de la otra, para ello las dos tarjetas se ensamblan en un clip para dedo construido con laminas de PVC espumado, un material ligero, rígido y durable. La Figura 9 muestra el dispositivo terminado. Este clip tiene $6 \mathrm{~cm}$ de largo, $2.5 \mathrm{~cm}$ de ancho y $3 \mathrm{~cm}$ de alto.

El núcleo principal del oxímetro de pulso conformado por el dispositivo ESP8266 se colocó en una pulsera, al igual que la batería. En la Figura 10 se ve al dispositivo final en funcionamiento.

El usuario puede observar sus niveles de oxígeno en la sangre y pulso cardíaco al ingresar en el sitio de la aplicación.

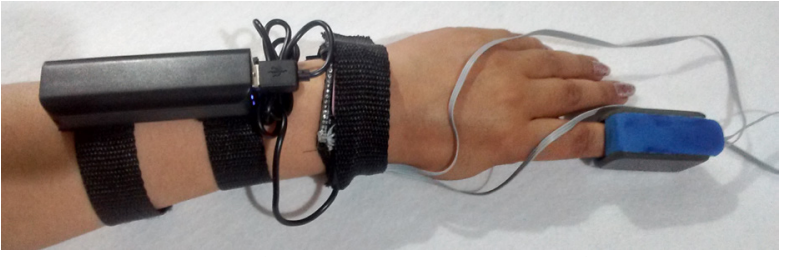

Figure 10. Final device / Dispositivo final

\section{Conclusión}

En este documento se presentó el prototipo de un oxímetro de pulso basado en el microcontrolador ESP8266 con conexión WiFi, el cual permite monitorear a distancia de la saturación de oxígeno y el pulso cardiaco, se logró mantener un monitoreo continuo, además de guardar un registro del mismo para su posterior análisis. En un futuro se busca perfeccionar el entorno gráfico, así como el control de los usuarios, además se plantea la implementación de este sistema a otros signos vitales. SST 


\section{References / Referencias}

AbuRahma, A. \& Bandyk, D. (2012). Noninvasive vascular diagnosis: A practical guide to therapy. London, UK: Springer.

Bencomo, S., Villazana, S., \& Salas, B. (2016). Diseño y construcción de un oxímetro de pulso. Revista Ingeniería UC, 23(2), 162-171.

Chopra, V. (2015). WebSocket essentials: Building apps with HTML5 Web-Sockets. Birmingham, UK: Packt.

Espressif. (2017). ESP8266EX Datasheet [v. 5.7]. Retrieved from: https://www.espressif.com/sites/default/files/documentation/Oa-esp8266ex_datasheet_en.pdf

Font, G. R., Pedret, C., Ramos, J., \& Ortís, L. C. (2008). Variabilidad de la frecuencia cardíaca: concepto, medidas y relación con aspectos clínicos (i). Archivos de medicina del deporte, 123, 41-48.

Gómez-García, C.A. \& Velasco-Medina, J. (2014). Sistema de pulsometría y capnografía para dispositivos móviles Android. Ingeniería Biomédica, 8(6), 36-44.

Koolman, J. \& Röhm, K. (2005). Bioquímica: texto y atlas. Bogotá, Colombia: Médica Panamericana.

Li, K. \& Warren, S. (2012). A wireless reflectance pulse oximeter with digital baseline control for unfiltered photoplethysmograms. IEEE Transactions on Biomedical Circuits and Systems, 6(3), 269-278.

López-Herranz, G. P. (2003). Oximetría de pulso: a la vanguardia en la monitorización no invasiva de la oxigenación. Revista Médica del Hospital General de México, 66(3), 160-169.

Marczenko, Z., Balcerzak, M., and Kloczko, E. (2000). Separation, preconcentration and spectrophotometry in inorganic analysis. Amsterdam, The Netherlands: Elsevier Science.

Mejía-Salas, H. \& Mejía-Suárez, M. (2012). Oximetría de pulso. Revista de la Sociedad Boliviana de Pediatría, 51(2), 149155.

Peñuela, O. A. (2005). Hemoglobina: una molécula modelo para el investigador. Colombia Médica, 36(3), 215-225.

Texas Instruments [TI]. (2015, June). OPT101 Monolithic photodiode and single-supply transimpedance amplifier. Retrieved from: http://www.ti.com/lit/ds/symlink/opt101.pdf

Texas Instruments [TI]. (2016). ADS111x ultra-small, low-power, I 2C-compatible, 860-SPS, 16-Bit ADCs with internal reference, oscillator, and programmable comparator. Retrieved from: http://www.ti.com/lit/ds/symlink/ads1115.pdf

Webster, J. (1997). Design of pulse oximeters. New York, NY: CRC. 


\section{CURRICULUM VITAE}

Gabriel Contreras Mota Engineer in Computer Science from the Benemérita Universidad Autónoma de Puebla (Mexico). Development of elements for Internet of Things [loT] is his main area of interest in research / Licenciado en Ingeniería en Ciencias de la Computación en la Benemérita Universidad Autónoma de Puebla (México), su principal área de interés en investigación es el desarrollo de elementos de Internet de las Cosas [loT].

Rafael Lemuz López Bachelor in Computer Science from the Benemérita Universidad Autónoma de Puebla [BUAP] (Mexico, 2002); Master and Doctor in Computer Science from the Instituto Nacional de Astrofísica, Óptica y Electrónica (Mexico, 2003 and 2008, respectively). Since 2008 he is a professor-researcher at the School of Computer Science of the BUAP. His research focuses on the development of mathematical and computational models for the processing of signals and images with applications in biomedicine / Licenciado en Ciencias de la Computación por la Benemérita Universidad Autónoma de Puebla [BUAP] (México, 2002); Maestro y Doctor en Ciencias de la Computación por el Instituto Nacional de Astrofísica, Óptica y Electrónica (México, 2003 y 2008, respectivamente). Desde 2008 es profesor-investigador en la Facultad de Ciencias de la Computación de la BUAP. Su investigación se enfoca en el desarrollo de modelos matemáticos y computacionales para el procesamiento de señales e imágenes con aplicaciones en biomedicina.

César Bautista Ramos Bachelor in Mathematics from the Benemérita Universidad Autónoma de Puebla [BUAP] (Mexico); Master and Doctor in Mathematical Sciences from the Universidad Nacional Autónoma de México [UNAM]. Full-time professor-researcher at the Faculty of Computer Science of the BUAP. His research areas of interest include: combinatorics, graph theory, quantum computing and mathematical and computational models for image processing / Licenciado en Matemáticas por la Benemérita Universidad Autónoma de Puebla (México); Maestro y Doctor en Ciencias Matemáticas por la Universidad Nacional Autónoma de México. Profesor-investigador de tiempo completo en la Facultad de Ciencias de la Computación de la Benemérita Universidad Autónoma de Puebla (México). Sus áreas de interés incluyen: combinatoria, teoría de grafos, computación cuántica y modelos matemáticos y computacionales para el procesamiento de imágenes. 